\title{
SPEJL PÅ VÆGGEN \\ - om selvrefleksionens variationer i Museum 2000
}

\author{
Line Hjorth
}

'Had the world gone mad?

And whose fault was it?

Hadn't it all started with the museums?

Sven Lindqvist, "Museums, Courage and Morals"

Museet er tingenes og materialernes sted, hverdagens, teknikkens, kunstens og naturens magasin, som det traditionelt set er opgaven at tage vare på, undersøge og gøre tilgangelige for offentligheden. Mindre etableret er opfattelsen, at museerne selv producerer et materiale. Betragter man imidlertid samme institutioners formålsparagraffer, registreringskort, udstillinger, pr-materiale, seminarer, konferencer og stemmer $i$ den offentlige debat som et sarligt museologisk stof, og lader man $i$ forlangelse heraf andre symbolske og imaginare betydningsprocesser talle med som f.eks. de uendelige keder af fortolkning og erfaring alt dette forer med sig, så tegner der sig et rids af museet som andet og mere end en skal til opbevaring og ordning af verden udenfor. Dertil kommer produktion af viden, den grundsten, museet traditionelt har bygget på fra de forste private samlinger og offentlige institutioners fremkomst. Museer er selv betydningsproducenter og manifesterer sig som medier med egne faglige og vardimassige forudsatninger, mål og interesser.

Ud over at tilbyde en kakofoni af museologisk tekst, viden om, idéer, kritik og holdninger til museets art og fremtidige rolle, er det i en selvreferentiel optik og med et fokus på museet som betydningsdanner, at bogen Museum 2000 - Confirmation or Challenge? med fordel kan læses. Værket er en kyndigt kommenteret opsummering af en forudgående serie på i alt seks svensk regionale seminarer og en storstilet international konference på Moderna Museet i Stockholm i 2001. Bag arrangementet står Riksutställningar, Svenska ICOM og Svenska museiföreningen.

I de indledende forord fremhæves to formålssætninger. Dels ønsker man at belyse museets fremtid forankret i rollen som 'forum 
i samfundsdebatten', dels vil man i et internationalt perspektiv at analysere og diskutere museernes fornyelse og forandringsarbejde. Således er perspektivet på en gang vendt mod museerne selv, uden at selvrefleksion af den grund er meget ekspliciteret i oplægget. Ligeledes er det vendt mod verden uden for museumsmurene i en stræben efter at belyse museet som aktør i en form, der rækker ud over historisk orienterede opgaver og frem imod en aktiv kritisk stillingtagen og påvirkning af begivenheder i det omgivende samfund.

\section{HISTORISK NUTID \\ OG ANTROPOLOGISK BLIK}

Når det giver mening at bruge selvrefleksion som en slags analytisk filter for bogens mange tekster, er det for det første, fordi begrebet som udgangspunkt udgør et grundsyn i arrangementet Museum 2000. Bevidstheden om museets virke i det, bogens redaktør Per-Uno Ågren i sin indledning betegner som museet i sin "historiske nutid" og af museet som betydningsfuld samfundsaktør, er den måde, hvorpå initiativtagerne klarest udlægger refleksionen. Tankegangen er central i en fortløbende svensk museumsdebat og udgør en væsentlig ramme for at forstå projektets karakter. Foruden Museum 2000 har dette endvidere udmøntet sig i konkrete udstillings- og museumsprojekter, der dog ikke skal omtales nærmere i denne artikel. ${ }^{1}$ Væsentligst at fremhæve her er det forhold, at de svenske museers "samtidsoptik" har bevirket, at diskussioner om museets art og funktion har fundet sted på mange niveauer og i mange fora, ligesom den har udmøntet sig i et mere direkte forhold og en klarere forståelse eller ligefrem og positiv accept af, at museet er et medium i sig selv. Man kunne frygte, at et fokus på den diffuse tids- angivelse "samtid" ville føre til en løsrivelse fra 151 museets historiske fundament og omdanne museet til tredimensionalt nyhedmedium underlagt hæsblæsende aktualitetskriterier, modeluner og ustadige publikumsinteresser. Da langsomhed imidlertid anerkendes som et grundlæggende musealt træk og samtid defineres som en allerede historisk størrelse, er det dog langt fra den drejning debatten og udstillingsmanifestationerne har taget ${ }^{2}$.

Skal man tydeliggøre en tendens i den generelle debat og i foretagendet Museum 2000, er det snarere et af antropologisk karakter rettet mod "andetheden" og mod minoriteter og undertrykte befolkningsgrupper, samt et multikulturelt samfunds mulige tilblivelse og udviklinger. Således diskuteres i bogen repræsentationer af jødedom, afro-amerikanere, voldsramte kvinder, indvandrere og immigranter $\mathrm{i}$ museet, ligesom der er tekster, som mere bredt anskuer multikulturalisme og identitetsdannelse som selvstændige fænomener. Endeligt er der bidrag, som frem for mere snævert at beskæftige sig med enkelte minoritetsgrupper, skærer helt ind til benet og blotlægger museet som historiens fremmeligste og mest effektive institution til forvrængning og forsimpling af sandhedens kompleksitet. "Why can the museum not address the problematic? What is this due to?", spørger den svenske forfattter Sven Lindqvist i sin artikel, Museums, Courage and Morals. Den beskriver bl.a., hvordan britiske museer i deres udstillinger har udeladt repræsentationer af den britiske hærs angreb på civile tyske mål under Anden Verdenskrig, samt en ligeledes hårrejsende beretning om den ideologiske kamp, der blev udkæmpet på The Air and Space Museum i Washington, da en ny museumsleder ville fortælle, hvad der faktisk skete i Hiroshima efter, den første atombombe blev kastet. Lindqvist giver ikke selv noget 
152 endeligt svar på sine spørgsmål, men de bliver hængende i luften som en skarp kritik af mange museers virke og som en fuld opbakning til den museumsstrategi, der vælger at blotlægge det fortrængte til åben beskuelse, græmmelse og raseri eller forløsning og lettelse. Når især Lindqvists bidrag skiller sig ud fra flere andre tekster, der ligeledes vil give plads til det fortrængte i museet, skyldes det især en vedvarende insisteren på og referencer til den videnskabelige historieforskning, hvorpå udstillingsrepræsentationer af f.eks. Anden Verdenskrig bør baseres.

Teksten skriver sig dermed op imod enhver form for tænkning, der tillader fortolkningsprocessen at vriste sig fri af videnskabeligt påviselige sandheder, britisk krigsførelses indvirkning på Holocaust eller Hiroshima efter atombombens fald. Det bekræfter ikke bare museumsgenstanden som et fysisk materielt vidnesbyrd om historiske begivenheder og tragedier; også museumsfolket må i dette spejl få øje på sig selv som dem, der har en specifik forskningsbaseret viden om tingene, en kompetence til at søge ny viden om disse og en forpligtelse til at give denne viden videre.

Under overskriften New Times - Separate Worlds får den "antropologiske" optik sin egen scene i bogen, der således følger seminarers og konferencens temaer ${ }^{3}$. Under denne titel markerer især de afrikanske lande sig med erfaringer og holdninger, der med stor sandsynlighed vil bevare en sørgelig aktualitet længe efter, at mange vestlige museer har fået opfyldt eller er kommet nærmere realiseringen af deres visioner. Mens den new zealandske kurator Ken Gorbey erklærer, at "museums are increasingly being required to act as one of society's most important gathering places in an age that increasingly recognises the multicultural and pluralistic nature of most com- munities and nations”; slår generaldirektøren for Kenyas nationale museer George H.O. Abungu fast, at dette langt fra er noget globalt scenario. Derimod er museer på det afrikanske kontinent "not a priority and must strive to create their own resources. Moreover, they must play a role that impacts on humanity directly if they are to attract funding from the central government."

De afrikanske museers behov for næsten at måtte legalisere deres virke over for regeringer og for at begrunde deres berettigelse $i$ håndfast nødvendighed på linie med skoler, hospitaler, vandforsyning og infrastruktur sætter vestlige museers virke som spektakulære oplevelsescentre i skinger kontrast. Dertil kommer en bevidsthed om en museumshistorie domineret af tidligere kolonimagters herrefolksideologier og statisk repræsentative museumskultur. Historien, refleksiviteten og det ny væves sammen inden for den logik, at det er nødvendigt nøje at kende til det fortidige for at kunne tage afstand fra det og sætte noget nyt i værk. På samme måde er der langt fra den engelske dekan og museolog Gaynor Kavanaghs sentimentalt og personligt betonede form for selvrefleksion, der ikke bare angår museet, men også beskueren til Abungu. Kavanagh tager afstand fra det, hun med et hint til historien betegner "antiquarianism" og argumenterer for museet som sted for "terapeutisk engagement" og "emotionel dannelse", hvor følelserne er udstillingens strategi og mål. Op imod det emotionelle, subjective og terapeutiske står så George H.O. Abungus klare historiske bevidsthed som et nødvendigt apparat, samt hans nøgterne efterlysning af museet som demokratisk diskussionssted, "a forum for dialogue, and a neutral ground where many voices at least have a chance of being heard even if it is not on an equal footing”. 


\section{VARIATIONER OVER ET TEMA}

Man kunne få det indtryk, at der eksisterer noget sådant som et Museum 2000, et spejlkabinet, hvori alle museer ser sig selv og får øje på omtrent de samme skæve problemer. At det forholder sig noget anderledes, og at bogen snarere former sig som variationer over selvrefleksionens tema, bliver snart tydeligt. Hvis det giver mening at anvende "selvrefleksion" som bredt samlende begreb for projektets idé og for de tendenser, der ligger til grund for Museum 2000, giver det også mening at anvende det på de enkelte bidrag for at få øje på deres budskaber. Hvordan spiller det selvrefleksive aspekt ind på tekstens tema? Eller sagt på en anden måde: Hvilken betydning tillægges studiet af museets egenart, dets rolle som betydningsdanner og normsætter? Hvordan kan selvrefleksionen kobles til ideen om museet som "forum for samfundsdebat"? Hvordan tolkes i det hele taget idéen om at museet skal reflektere over sin egen art og bestemmelse? Det fremgår, at der er skarpt divergerende opfattelser af, hvad refleksionen mere præcist har som sit objekt. Desuden er det karakteristisk, at tekster, der bedst belyser relationen mellem det indadvendte og det udadvendte, museets selvbevidsthed og selvkritik og så det at fungere som aktør i en større samfundsmæssig kontekst, er de tekster, der meget bevidst gør sig museets historiske fundament, idéer og funktioner klart.

To forfattere markerer sig som udprægede eksponenter for selvtematiseringen som en egen metodik og museologisk strategi, den amerikanske universitetsprofessor Barbara Kirshenblatt-Gimblett, samt den amerikanske kunstner Fred Wilson. Kirshenblatt-Gimblett udpeger i sin tekst om "Museet som katalysator" tre måder, hvorpå selvreferensen kommer til udtryk i en række eksisterende museer og museumsprojekter. Som det første eksempel nævnes "metamuseerne", museer fra 1800-tallet, der i dag er blevet en slags historiske monumenter over sig selv og en bestemt epoke, samt over den historiske genstand som museets alfa omega, f.eks. Sir John Soanes museum i London, Tylers museum i Harlem, Hallwylska Palatset i Stockholm og the Mütter Museum of the College of Physicians of Philadelphia.

En anden udgave af selvrefleksionen er den, hvor museet forvaltes som kunstorienteret praksis og "auto-poetisk" system. Det autopoetiske indebærer, at uanset hvor meget museet præsenterer genstande, som er bragt ind i det, er det til syvende og sidst et selvreferentielt system. Det betyder ikke, at museet er isoleret fra resten af samfundet, men derimod at museet ved at fokusere på sin egenart kan skabe helt nye muligheder og markante oplevelser som f.eks. kunstmuseet KEOM, der i 1902 åbnede som Folkwang Museum i Hagen. Endelig fremhæver Kirshenblatt-Gimblett en "projekt-model" for museet, hvor det i stedet for at opfatte sig selv som afgrænset, statisk institution, låner fra en samtidskunstnerisk praksis, der lader kunst opstå i gensidig udveksling med ikke-kunst, en art "social skulptur", der forandres afhængigt af de kontekster projektidéen placeres i. Udstillingsprojektet "Svåra Saker" ses som et idealeksempel på en sådan "performativ museologi", hvor de besøgende hele tiden tilfører udstillingen nyt stof og deltager i dokumentationen af tingene som medproducenter (jf. note 1).

Forankringen i museets egen historie og materiale kendetegner også den afro-amerikanske billedkunstner Fred Wilsons praksis. I en række markante udstillingsscenografier har Wilson forskudt og eksponeret elementer i museets vanlige opstillinger, hvor ethvert tegn 
154 i museet, objekter, rum, kustoder, lys og lyd, optræder som potentielle skabere af betydning. Særligt har Wilsons blik været møntet på amerikanske historiske museer som autoritære magtfaktorer og forvrænger af en sort befolknings historie. Ved at kulegrave samlinger åbnes for hengemt eller skjult viden. Undertrykte eksistensers liv og fortælling kommer frem $i$ lyset i en kontrafaktisk og subjektiv præget udstillingsform, der modsætter sig en dominerende amerikansk "neutral" historiediskurs.

\section{Museologisk SPEJLKABINET}

Der er således langt mellem nogle af de udtryk selvrefleksionen antager i projektet $\mathrm{Mu}-$ seum 2000, der i kraft af emnernes spændvidde, teksternes antal og diskussionernes omfang tager sig ud som en museumskonferencernes blockbuster med tilhørende kilotungt milleniumkatalog. I lighed med blockbusterens størrelsesbestemte form risikerer også et seminarprojekt som det svenske at føre til en vis grad af forvildelse og desorientering. Men Museum 2000-seminarer og -konference var, og Museum 2000-bogen er først og fremmest et stoppested for refleksion over nogle af de grundlæggende museologiske spørgsmål, der nok rumsterer i en travl museumshverdag, men sjældent for rum og tid til at folde sig ud.

Skal man anskue projektet $i$ et kritisk perspektiv (og ve den der kommer gennem bogen uden at fatte, at kritik og refleksion må der til!), vil det være, at afstande og forskelle mellem synspunkterne med fordel kunne være trukket tydeligere op. Frem for at følge seminarer og konferencens megalomane form og lade bogen være en slags tekstligt og grafisk print af en række forelæsninger, diskussioner og workshoprapporter, kunne det have været en mulighed at lægge et kritisk snit på tværs af de mange tekster og stillet holdningerne skarpere op mod hinanden. Det ville fra første blik have knust enhver illusion om et universelt forbundet "Museum 2000". I museumsrapportens fyldige og opsummerende form bydes nutidige og kommende museumsfolk og museologistuderende imidlertid på en rivende frodig og oplysende tour de force i et samlet, men vidt facetteret musealt spejlkabinet; et Museum 2000, hvor læseren i mødet med tekster og billeder selv må forsøge at finde rundt $i$ alle de mere eller mindre skæve genspejlinger. På tværs af overskrifter og kapitler øjner hun så måske, hvad museer er, hvad de kan, hvad de skal. Og det er i grunden en proces, der for den opmærksomme læser byder sig til som slet ikke så uvæsentlig pointe.

\section{Noter}

1. Blandt disse kan nævnes udstillingerne Svåra saker (www.svarasaker.riksutstallningar.se), Toppmötet (www.riksutstallningar.se) og Malmö museers Migrating Memories

(www.migratingmemories.net). Se desuden om Samdoksekretariatets virke i Samtid\&Museer, nr 3-4, 2002, årg. 26, bl.a. forord v. redaktør Eva Silvén.

2. Se også L. Hjorth "Til Fest for en udstilling refleksioner over Nordisk Museumsfestival i Stavanger", Danske Museer nr. 6, dec. 2000.

3. Bogen (Museum 2000 - Confirmation or Challenge. Stockholm 2002, ISBN91-7057-055-8.

Distr. Riksutställningar, Stockholm) er opdelt i tre hovedtemaer: New Times - Separate Worlds; Artefact, Memory, Narrative; Museums and Morals, rummer dertil et afsnit med kommentarer og refleksioner med samme overskrifter.

Line Hjort er ph.d. studerende, Institut for Kunsthistorie, Aarhus Universitet. e-mail: line.hjorth@jubiipost.dk 